
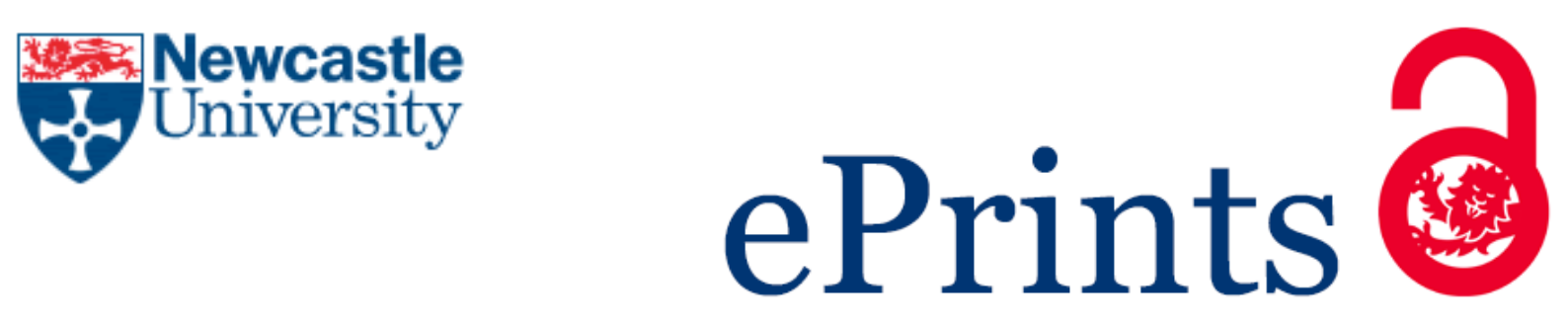

Whittle A, Mueller F. Intra-preneurship and enrolment: Building networks of ideas. Organization 2008, 15(3), 445-462.

\title{
Copyright:
}

This is an authors' accepted manuscript of an article published in Organization, 2008

The definitive version of this article, published by Sage, 2008 , is available at:

http://dx.doi.org/10.1177/1350508408088539

DOI link to article:

http://dx.doi.org/10.1177/1350508408088539

Date deposited:

$14 / 05 / 2015$

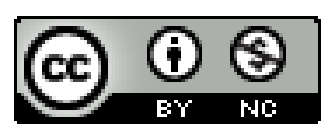

This work is licensed under a Creative Commons Attribution-NonCommercial 3.0 Unported License 
This is the author(s) personal version of the manuscript, as accepted after the review process but prior to final layout and copyediting by the publisher. The final version is published as:

Whittle, A. \& Mueller, F. (2008) Intra-preneurship and Enrolment: Building Networks of Ideas. Organization 15(3): 445-462.

Readerssearchers are kindly asked to use the official publication in references.
Formatted: Font: $10 \mathrm{pt}$

Formatted: Indent: First line: $0 \mathrm{~cm}$

Formatted: Left

\section{Intra-preneurship and Enrolment: Building Networks of Ideas}

Andrea Whittle (1) and Frank Mueller (2)

(1) Cardiff Business School

$$
\text { Cardiff CF10 3EU }
$$

whittlea@cardiff.ac.uk

(2) School of Management, University of St Andrews, St Andrews, KY16 9SS, Scotland, U.K.,

frankmueller100@yahoo.co.uk 


\section{ABSTRACT [195]}

In this paper we draw on and develop an actor-network perspective on organizational entrepreneurship - the study of enterprising behaviour within the firm. Based on the findings of an in-depth study of management consultants in a UK telecommunications firm, we argue that ideas do not flourish because they are inherently more 'enterprising' or 'innovative' than others, but rather because of the success (or otherwise) of the process of 'enrolment'. Our study shows that the consultants were not 'intermediaries without discretion', tasked with the diffusion of an already-established template. Rather, they acted as mediators by actively seeking to construct and maintain a network around their idea. By revealing the political tactics and power plays involved in this enrolment process, our study contributes to the actor-network literature by highlighting the link to organizational power and politics. The study also contributes by drawing attention to the subjectivity of network-builders - an issue often left underexplored in actor-network studies. We illuminate the identity processes involved in organizational entrepreneurship, including the link to systems of organizational control. This was fuelled by a mixture of anxiety, insecurity and the desire to be recognised as an 'intra-preneur'.

Keywords. Actor network theory. Mediator. Enterprise. Identity. 


\section{Introduction}

In much of the existing literature on organizational entrepreneurship (eg Kanter, 1985, 2000; Peters, 1992), the question of how employees come to desire an identity as an 'intrapreneur' and what practices are involved in making an idea 'enterprising', is left unaddressed. If, as Kanter (1985: 20) argues, being an 'ideas champion' involves a "process of bringing any new problem solving idea into use", it cannot be assumed that ideas start off being recognized as 'enterprising' and their creators are automatically confirmed as 'intra-preneurs'. Rather, we suggest, we must study the process through which a more or less robust network around an idea is generated and maintained. In this paper we draw on an ethnographic study of a consultancy team (FlexiTeam ${ }^{1}$ ) within a large UK telecoms company (TeleCo) to reveal the practices involved in making an idea 'enterprising' and constructing an identity as an intrapreneur.

While much is known about how consultants enrol clients into viewing their products and services as desirable (see eg. Clark, 1995; Berglund and Werr, 2000; Sandberg and Werr, 2003; Clark and Fincham, 2002), much less is known about how new concepts and services are developed within the firm (exceptions are Fosstenløkken et al, 2003 and Thomas, 2003). This paper tracks the 'messianic mission' of a group of consultants as they attempt to secure the status of their ideas as enterprising and in turn secure their identity as intrapreneurs. By drawing on ideas from the sociology of translation, we reveal the heterogeneous engineering that goes on 'behind the scenes' to create enterprising ideas. We show how workers act not so much as functional intermediaries for furthering the interests of the firm, but rather as mediators (Latour, 2005: 39) of the search for the entrepreneurial organization.

The next section outlines the theoretical underpinnings of our approach. The third section outlines the methodology employed in the study. We will then briefly introduce FlexiTeam, before moving on to present the insights derived from the empirical data. Fifth and finally, we consider the implications of our work for theory development. 


\section{Theorizing Enterprise}

Why do some ideas become recognised as 'enterprising' while others are not? One useful source of inspiration for addressing this question can be found in a body of work developed within science and technology studies that has become increasingly popular within organization studies (eg. Czarniawska and Hernes, 2005). The sociology of translation, or Actor-Network Theory (ANT) as it is more commonly known, has been used to show how networks are built to make scientific knowledge into 'truth' (eg. Latour, 1987), how technologies are translated into viable 'innovations' (eg. Callon, 1986), how long-distance colonies are controlled (Law, 1986), and how mundane problems of missing hotel keys are solved (Latour, 1991). Due to space limitations, we are unfortunately unable to offer a full overview of this literature here ${ }^{2}$. In what follows, we discuss the central ideas from ANT that contribute to our understanding of enterprise as a network.

According to Latour (1987), gaining the status of 'truth' depends on the assembly of a robust network of research, articles, scientific equipment, tables, diagrams, charts, research assistants and scientific allies. Accordingly, we build on previous work on the diffusion of ideas (Czarniawska \& Joerges, 1996; Sturdy, 2004; Czarniawska \& Sevón, 2005) by arguing that entrepreneurship can also be understood in terms of the construction of a durable network around a particular idea. In other words, ideas and practices do not start life as 'innovative' and 'entrepreneurial' but rather must be made as such and will only remain as such as long as others remain faithful to the network. To understand this process we must therefore follow those actors who "actively carry out the task of assembling the network and making it into a centre of authority" (Gherardi \& Nicolini, 2005: 287) - indeed, management ideas do not simply get adopted but rather get translated in complex and variable processes at the micro level (Morris \& Lancaster, 2006; Zilber, 2006).

As Gherardi and Nicolini (2005: 289) point out, ANT-inspired studies have tended to focus on the power and durability of networks. This 'entrepreneurial' or 'heroic' narrative tends to map the flow of power from a central authority and chart the role of faithful intermediaries in extending its control over time and space (ibid). By making the 
centre the "favoured vantage point" (Helgesson \& Kjellberg, 2005: 146), the role of dissidents, the 'small wins' of everyday negotiations and those at the periphery tends to be left out of the story. However, literature on technology and information systems, including some inspired by ANT, has in fact advanced our understanding of those at the periphery of networks and those who resist enrolment (see eg. Orlikowski, 1996; McGrath, 2002; Faraj, Kwon \& Watts, 2004), such as people who are allergic to onions but faced with standardised food in a fast-food restaurant, for example (Star, 1991). In this paper we build on this work in two key respects.

First, we examine organizational entrepreneurship from the perspective of those at the periphery: those struggling to construct a network and facing daily challenges to the network-in-the-making. We argue that these everyday practices of network-building and network-maintenance do not represent an alternative and complementary view of translation, as Gherardi and Nicolini (2005) suggest, but rather comprise the 'behind the scenes' praxis hidden within 'heroic' or 'entreprenuerial' narratives.

Second, we bring the subjective processes of network-building to the forefront of the analysis. ANT's focus on networks has tended to skip over the subjectivity of the network-builder and the political and power relations that shape how network-builders come to see themselves and their motives (Whittle \& Spicer, 2008). In this study we highlight the insecurity and fragility experienced by the consultants as they strove to construct an identity as 'intra-preneurs'. We argue that the consultants were not passive intermediaries of an already-institutionalised template, acting as passive funnels for the idea of flexible working (Latour, 2005: 39). Rather, their quest for an identity as 'intrapreneurs' led them to actively mediate (Latour, 2005: 39) (i.e. change) definitions of the 'interests' of the firm, by striving to construct a robust network of allies around their innovation and place themselves at the centre of the network of organizational power.

\section{Methodology}

Research Participants. FlexiTeam were a group of ten 'flexible working' consultants employed by UK telecommunications firm TeleCo. The consultants used the term 'flexible working' broadly to refer to the use of technology to work flexibly in time 
and/or space. FlexiTeam advised external clients on how to implement home-working, hot-desking, mobile working, virtual teams and related facilities management, human resource management and real estate issues. Their consultancy methodology included questionnaires, interviews, focus groups, workshops, geographical mapping technology and space utilisation surveys.

Data collection. The study took an ethnographic approach and sought to gain an indepth understanding of the working lives of the consultants through non-participant observation and semi-structured interviewing. The fieldwork was conducted between 1999 and 2003 and involved non-participant observation of team meetings, one-to-one performance reviews, exhibition and presentation activities, client workshops, sales events, home visits and social activities, in addition to gathering documentation and studying audio-conferences and email exchanges within FlexiTeam (see Table in Appendix). The semi-structured interviews were also adapted to include questions based on the ongoing insight derived from the fieldwork observations. In total, the study generated four notebooks of field-notes, over a hundred email exchanges, over sixty hours of tape-recorded interviews and audio-conference recordings and numerous paper and electronic documents, leaflets, brochures and files.

Data analysis. As an inductive and exploratory study, the aim of data analysis was not to compare the results with pre-defined hypotheses. Instead of simply reproducing the emic interpretations that were prevalent in the field, we wanted to work at the boundary between the emic and etic, in order to produce a new interpretation of 'what is going on here' (Barley, 1996). Given that the consultants already promoted their own 'emic' narrative about flexible working through newspaper stories, speeches, exhibitions, brochures, merely repeating these stories would be unlikely to add much to theory development. The themes and sub-titles used in this article were therefore constructed through an iterative movement between the data and our reading of the literature, in particular with inspiration from ANT. As Bryman (1988) points out, decisions about how to design a study and what constitutes 'data' (including how, when, what and why to gather it) are always informed by the personal, political and theoretical perspective of the ethnographer. 


\section{Understanding Enrolment: The Case of FlexiTeam}

At the start of the study, the researcher expected to spend the majority of the ethnography studying how the consultants attempted to enrol clients into their 'flexible working' idea. It was assumed that flexible working represented an obvious opportunity for their employers, TeleCo, to find an innovative source of market potential for their telecommunication products and services. Indeed, as one senior manager told the researcher during access negotiations:

You know why TeleCo is so keen on flexible working don't you? It's so they can show it works and sell more kit.

In other words, the consultancy approach was assumed to help to convince clients that they should be more 'flexible' - for example, by enabling the workforce to work from home or 'on the road' - in order to create new markets for products such as broadband connections and mobile phones. In 'translation' terms, then, the researcher assumed that FlexiTeam were an intermediary (Latour, 2005) of the firm, merely transporting and extending the company's techno-utopian message about the virtues of technologyenabled flexibility. Flexible working consulting seemed like a transparently 'enterprising' idea for a telecommunications firm. The consultants were therefore expected to act merely as an intermediary that "transports, transfers, transmits" (ibid: 77) from the powerful centre.

As the researcher spent more time observing the consultants day-to-day lives, however, a different picture emerged. The consultants did indeed dedicate much of their time and energy to convincing clients that flexible working was both desirable (to stimulate interest in the idea) and problematic (to stimulate demand for consulting advice). Yet the study also uncovered an unexpected world within the firm, where the status of the flexible working idea as 'enterprising' was contested and their identity as ‘intra-preneurs' was challenged.

\section{Building an 'Enterprise' Network}


TeleCo's relationship with flexible working dates back to 1993 when the company conducted its first 'teleworking' trial in a remote area of Scotland. TeleCo now boasts the UK's largest corporate flexible working program, branded 'Work-anywhere', with over 5,000 officially registered home-based workers and over 80,000 staff with remote access facilities. TeleCo is widely recognised as an enterprising pioneer in establishing what is now largely taken-for-granted as a method of achieving the flexible deployment of labour. It was the high-profile success of the Work-anywhere program that enabled the program manager, Eric, to set up FlexiTeam. How, then, was this translation of the idea from a small pilot project to the UK's largest flexible working program to one of the first specialist flexible working consulting groups - achieved?

Eric, FlexiTeam's team leader, described his role in 'selling' the idea to senior management:

There was the MBA project that I sold to the company about flexible working basically. The 'Work-anywhere' program emerged out of that. We did lots of work within TeleCo... launching a massive program, 70 people involved. Again, on the back of a big property project - moving out of London.

Underlying this narrative is a constellation of heterogeneous actors, actions and events: an existing interest in teleworking (trials in Scotland), a property project (moving out of expensive London locations), an MBA dissertation, career ambitions, and the persuasion and negotiation involved in the 'sales pitch' to senior management. Furthermore, the 'Work-anywhere' program also came up against a range of hurdles. In addition to technical difficulties, the program faced resistance from line managers, staff and families struggling to adjust to 'work coming home'.

Following the Work-anywhere program, there was certainly no necessary reason for TeleCo to branch out into selling flexible working in the form of consultancy services. TeleCo was a telecommunications service provider and retailer, not a consultancy firm. Eric narrated in our interview how this ‘innovation' was brought about:

Then in '97 we were doing quite a lot of work outside of TeleCo. Clients kept coming to us, so we approached the TeleCo division board and suggested that we could take this 
outside TeleCo. ... I always wanted to run my own business. ... Effectively that's what I've done with this team. I've created it from scratch.

While presented here by Eric in a somewhat linear and heroic storyline, as per Gherardi and Nicolini's (2005) 'entrepreneurial' narrative', considerable labour on the part of Eric (among others) was required to enrol different actors into viewing flexible working as an innovative corporate venture. Eric can be seen as a key mediator who transformed flexible working from an idea within an MBA project, to a major organizational change program, to an external consulting offering. Prior to this network-building, flexible working was nothing more than a small pilot project in a remote area of Scotland. This mediation, we suggest, is linked to Eric's desire to be identified as an innovator who, in effect, created his "own business". The status of the idea as 'enterprising' was thereby achieved as a result of, amongst other things, the identity work (Svenningsson \& Alvesson, 2003) of its founder. We will discuss the issue of identity in more detail below.

\section{Defending the Network}

At the time of the study, FlexiTeam had assembled a network of allies that had positioned them in a senior status in the organizational hierarchy, accompanied by a generous remuneration and benefits package and high levels of discretion in their day-to-day consultancy work. However, this status, ownership and autonomy also brought with it distinct forms of responsibility, accountability and anxiety. Organizational politics was a major source of anxiety for the consultants that threatened their network and their identity as value-adding 'intrapreneurs'.

\section{Spotting the Wolf in Sheep's Clothing}

During the fieldwork, the consultants often expressed concern about being merged, taken over or replaced by another 'rival' group within TeleCo. Senior consultant Barry described one such occasion in our interview:

[Department A] thought they could do flexible working consultancy, but we had track record internally, the story to tell. ... They asked can we meet to discuss how we can work together, we said 'sure', but they were after our info and knowledge, and not 
working collaboratively. And [Department A] had a bad reputation so you don't wanna be tarred with that same brush.

In network-building terms, the consultants engaged in continual surveillance to defend against 'hidden' enemies - those who appeared on the surface as 'allies' but wanted to steal their 'intellectual property'. Throughout the fieldwork, the researcher observed an ongoing political project to defend their ownership of their ideas. For example, the following 'warning email' was sent by consultant Barry to the group distribution list, regarding their previous experience when trying to partner with another business unit.

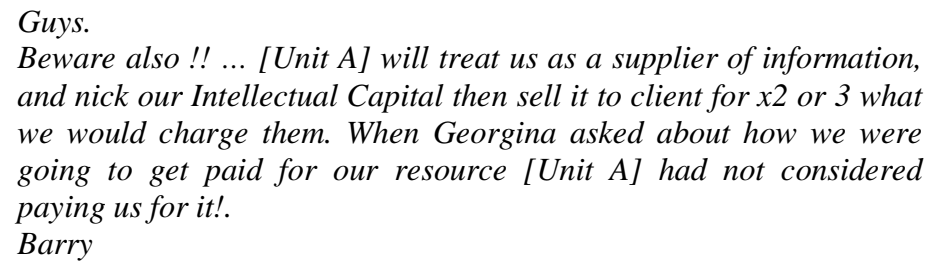

In short, the consultants needed to be cunning to maintain their network - able to spot the wolf in disguise as an innocuous sheep.

\section{The Custody Battle}

This sense of internal competition around ownership of 'ideas' is one of the outcomes of the simulated 'quasi-markets' associated with post-bureaucratic transformations. Indeed, maintaining the strength and durability of their network depended on the consultants' ability to win the battle over 'custody' of clients. This required some serious political gaming. For instance, the following extract from a team meeting shows how consultant Kevin attempted to enrol the departmental manager, Tim, into defending their custody of the revenue from the client referrals that come through account managers: 
Kevin: There needs to be a proper channel to FlexiTeam when an Account Manager gets a client interested in flexible working, so they don't send them to [Unit A] or [Unit B]. We need to have the internal profile so that we come to mind first.

Tim: I agree, we do need to work on publicity. They need to know what you do. You need the internal publicity.

As the extract above suggests, political gaming was not only a matter of shielding against internal rivalry. FlexiTeam also sought to gain internal publicity, generate an internal profile and construct internal alliances that would benefit the profitability of their consulting unit. For example, the team fought to get 'flexible working consultancy' added to the database used by account managers. As account managers could now receive a bonus for resulting consultancy revenue, FlexiTeam hoped this would act as an incentive for them to pass on client queries about flexible working. From an actor-network perspective, the consultants employed crafty methods to make themselves the obligatory passage point between clients interested in flexible working and other departments in the firm. This was a process of heterogeneous engineering, that is, enrolling faithful human (eg. account managers, senior management) and non-human allies (eg. the database, bonus payment systems).

\section{Staying at the Top of the Food Chain}

The consultants seemed to be well aware of the fragility of their network, particularly when their alliances and power-bases were shaken up during the seemingly endless series of corporate restructurings. The fear of being disbanded or downgraded (in terms of size, status or resources) was a constant source of debate during lunch-time conversations. It was no surprise, therefore, that this theme emerged during the interviews as well. As consultant Duncan described:

We bounce around and have been reporting to various people. I've been through 2 [restructurings] but they were going on 3-4 a year, which makes me a little bit nervous. 
Consultant Barry was in no doubt about where the 'praise' should go for defending their network in such times of turmoil.

Eric was clever- he was trying to position the team. We were being pulled in different directions and he said basically we don't wanna be there, we wanna be basically at the top of the food chain.

There were frequent episodes of downsizing and restructuring and one of the challenges was "to protect or insulate the team against all this TeleCo crap" (Interview with Eric). What practices were involved in this? As one such corporate restructuring exercise occurred during the fieldwork, the researcher was fortunate enough to observe these practices firsthand. One good example was the first meeting between consultants and their newly allocated business section 'boss'. During the meeting, the consultants made an elaborate show of emphasising the value they added to the business, for instance by carefully 'slipping in' details of large contracts they had recently secured. During this political 'show', consultant Barry was keen to convince their new manager of the value they add to client relationships:

We all know that the relationship with the client is key, and when the account manager in TeleCo leaves, we are the relationship. Besides, we don't just know the [client] IT people, we get in at a strategic level, with the CEO, finance, property.

With each restructuring exercise, their position was rendered fragile. The process of mediation was again heightened during meetings like this. Old allies must be kept faithful, but crucially also the new power-centres created by the restructuring exercise must be actively recruited into the network. In everyday practices of political persuasion during routine meetings such as this, the consultants were active mediators seeking to convince those with the power and resources that flexible working consulting was an 'innovative', 'value-adding' and 'enterprising' concept. 


\section{Playing the Numbers Game}

While the consultants used persuasive rhetoric in the meeting described above, words alone were insufficient for maintaining their network. The management accounting system in particular presented a significant challenge to their network and required winning a numbers game as well as a word game. In managerialist regimes, accountability to users/customers/shareholders is measured by satisfaction ratings, performance league tables etc (Clarke and Newman, 1997: 65-66) as opposed to bureaucratic principles. In TeleCo, market mechanisms were simulated by the creation of cost centres or budget holders, which were held accountable for the creation of surplus value at the level of the individual business unit (Deetz, 1998). Consultant Nigel explained how this accounting system made their business unit look at best precarious and at worst untenable:

We are an expensive luxury. If we worked for any other corporate, we wouldn't be there. ... In terms of ratios we're covering our overheads, but we're not generating profit. Or the profits and revenues that we generate are identified somewhere else and would never be correlated back to us.... It's the way they're measuring us.

As Nigel explained, the 'value' of consultant's network was challenged by the network of numbers constructed by the accounting regime. Their ability to act as spokespersons of an 'enterprising' and 'value-adding' innovation seemed to depend on navigating these regimes of corporate accounting.

Perhaps not surprisingly, the consultants were not passive intermediaries in this accounting network. Rather than accepting this 'technology of managing' as a mirror on the self for the purposes of self-audit (Munro, 1999), the consultants actively sought to challenge the 'unprofitable' problematisation created by the accounting regime. Throughout the fieldwork the researcher made notes of the conversations with senior managers, such as the extract from Barry's speech at a team meeting above, where the consultants stressed how unfaithful the accounting network was - it failed to notice the 'hidden' value they created that was “never correlated back to us". Defending their 
network therefore involved convincing their superiors that the problematisation created by the accounting network - which presented them as an 'unprofitable' rather than ‘innovative’ unit - could not be trusted.

The consultants also employed a range of micro-tactics to demonstrate their 'addedvalue'. From observing the email exchanges within the group, the researcher learnt about one creative workaround to the existing cost centre accounting system - the consultants began to start 'billing' other departments for work they were asked to conduct. While corporate conferences and exhibitions were one source of new client business, these events were not 'billable' to any particular client and as such did not contribute to their income/cost ratio. The following email was sent by team leader Eric in response to a request by event manager Beverley:

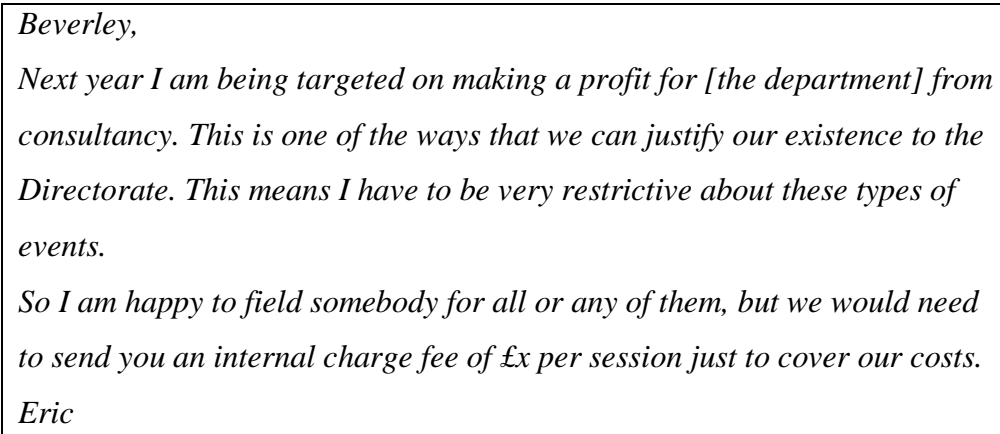

Eric was explicit here in his instrumental attitude to 'working around' the accounting system in order to 'justify their existence' and maintain their network. The consultants seemed to be actively aware of how to 'play the game' to get the right numbers. As Munro (1999) argues, 'centres of discretion' often emerge alongside 'centres of calculation' like accounting regimes.

We suggest it is these forms of behind-the-scenes micro-political tactics (Buchanan \& Badham, 1999) through which enterprise networks are constructed, in this case by working in, around and against the system of accounting and measurement. The consultants thus acted as mediators who strove to transform their idea into an innovation which was legitimate as seen through the network of accounting calculations. To sum up, 
our key argument is that without these everyday 'behind the scenes' practices, flexible working would fail to be recognised as an 'enterprising' idea.

\section{Becoming an 'Intrapreneur'}

Why did the consultants engage in this mediation we describe? As Clarke and Newman (1997) point out, there are obvious material consequences of successfully mediating what is seen as 'innovative' and in the 'best interests' of the firm, as it enables groups to "legitimate a particular set of objectives and the allocation of resources that may follow from them" (p. 117). Indeed, it is understandable that the consultants engaged in the political tactics we described above to make themselves appear 'innovative' and 'profitable', for example, given that both their job security and performance-related pay were at stake. However, our aim here is to focus on the link between the practices of mediation and the desire for an identity as an innovative employee or 'intra-preneur' (du Gay, 1996).

Deetz (1998) reveals the way in which accounting techniques are used as a form of organizational control. His study revealed the anxiety and insecurity, but also selfdiscipline, produced when a department was transformed into a cost centre that was responsible for the generation of profit. In short, the creation of a new breed of 'intrapreneurs' acted as a form of organizational control that worked through employees' sense of self. Similarly, in our study, the idea of flexible working consultancy seemed to be closely linked to the desire of the founder of the team, Eric, to construct an identity as an 'intrapreneur'. Indeed, Eric's colleagues described the passion that underlay the instigation of flexible working within the firm:

Eric runs it as almost a personal crusade as well, he's passionate about the whole subject ... and the way he fights it internally in ways we sometimes don't even know or appreciate it.

(Terry, Consultant) 
While this messianic passion seemed to rub off on the other consultants, the team were also well aware of the expectations placed upon employees to 'add value' - leading to anxiety around whether their network was robust enough to survive:

The company has gone through massive changes .... It's a new company now and if you're not gonna pull your weight and be committed to the team or your own individual job then you're not going to survive.

(Darren, Consultant)

Conversations over lunch and drinks after work often returned to the issue of whether they would 'survive' in the competitive marketplace for ideas within TeleCo. Duncan explained more in our interview:

So that we have survival, survival in the organisation, we're constantly trying to get new clients in. Especially in TeleCo and with the turmoil you've always gotta think about the future. Sad to say, but how are you gonna last?

(Duncan, Consultant)

This climate of insecurity led to powerful effects on the consultants' sense of self. The researcher was surprised by the way in which the consultants seemed personally invested in the need to find innovative new ways of adding value through their consultancy work. These findings suggest an ambivalent mixture of enthusiasm and commitment towards being a 'value adding' intra-preneur, 'in business for themselves', coupled with a fragile and insecure sense of identity. This mixture appeared to be fuelled by the recurrent anxiety and ambiguity around whether their identity as intra-preneurs would be confirmed or contested - as the interview extracts from consultants Darren and Duncan cited above indicate.

\section{Discussion, Conclusion and Implications}




\section{The Mediation of Enterprise Discourse}

On the surface, flexible working consultancy would appear to represent obvious potential for opening up new market opportunities for the sale of telecommunications products and services. Hence, we expected that the idea - solving client problems rather than selling product features - would be readily recognised as an 'innovation'. The consultants were therefore assumed to act as an intermediary for furthering the interests of the firm, by enrolling clients into the vision of technology-enabled flexibility. While the study did indeed uncover a range of tactics used by the consultants to make themselves indispensable to clients - as per other studies of consultant-client interactions (Sturdy, 1997; Mueller \& Dyerson, 1999; Fincham, 1999; Berglund \& Werr, 2000) - the study also found that the consultants did not act as passive intermediaries of the firm, letting ideas pass without modification or distortion (Latour, 2005: 39).

By studying the consultants over an extended period of time, we observed the practices of network-building and network-defence through which the consultants attempted to position themselves as 'obligatory points of passage' (Callon, 1986) for the firm. Flexible working was not an already-institutionalised idea - rather, a network had to be built, defended and maintained to make it such. The consultants struggled to be recognised as spokespersons of an idea that would create 'enterprising' new market opportunities and further the interests of the firm. The strength of their network depended on their ability to convince their employers that their interests were best furthered through membership of their network. In fact, the struggle was not around how to resist attempts by the firm to make them 'intra-preneurs' but, rather, how to overcome resistance and challenges to their status as enterprising employees. Clarke and Newman (1997: 117) have shown how claiming to represent the 'best interests of the customer' enables organizational groups to gain power and resources. Similarly, our study reveals the political motives involved in claiming to have the most innovative idea to further the 'best interests of the firm'.

To sum up, the consultants in our study were not simply 'intermediaries without discretion' (Munro, 1999: 438), tasked with the diffusion of an already-established template. Rather, they acted as mediators who sought to actively construct and maintain their legitimacy as spokespersons of an enterprising idea - in the context of an ongoing 
battle in the 'marketplace for ideas' within the firm. This study builds on existing literature on the movement of ideas (Sturdy, 2004; Czarniawska \& Joerges, 1996; Czarniawska \& Sevón, 2005; Morris \& Lancaster, 2006; Zilber, 2006) by highlighting the way in which ideas are actively translated rather than passively diffused by actors. Moreover, our analysis has also linked this battle to the search for an identity as 'intrapreneur'.

\section{The Production of Enterprising Selves}

This article has focused on organizational entrepreneurship and the attempts to create an enterprising "culture" within the firm. Enterprise culture invites employees to abandon traditional attachments in favour of identification with a shared, strong corporate culture (Clarke and Newman, 1997: 62). In place of fixed bureau-professional roles, employees are encouraged to internalise the over-riding mission and values of the organisation and be flexible and creative in pursuit of organizational goals (Casey, 1995). In this new 'transparent organisation', "everyone is responsible for achieving corporate objectives and everyone is enterprising in pursuit of them” (Clarke and Newman, 1997: 62). Such attempts to link the enterprising subject to the enterprise organization involve "virtual

selves ... being artificially constructed to suit corporate purposes” (Collinson, 2003: 542). The desire to work upon the self (Giddens, 2006) creates a continuous process of 'self-surveillance' and 'self-improvement' in service of the corporate objectives (Deetz, 1998). The self becomes a means through which to achieve the objectives of the firm (Deetz, 1998) and work becomes "an essential element in the path to self-fulfilment" (Rose, 1999: 119).

\section{Networks and their Builders}

Actor-network theory has provided a useful analytical framework for understanding the practices through which networks of ideas are built and maintained. Indeed, the findings of this study resonate with Callon's (1986) seminal study of scallop fishing, most notably in how the scientists convinced the fishermen that their research project was the best way to further their interests and preserve the scallop stock. Similarities can also be drawn with Latour's (1987) study of how scientists enrol a robust network of equipment, 
researchers, journals and funding bodies in order to construct scientific 'truth'. In our study, the strength of the network depended on the consultants' ability to enrol actors within the firm - not only clients - into the idea that flexible working consultancy was a viable and valuable 'innovation' and the best way to further their own interests. As we have seen above, this battle was played out in the daily political micro-tactics of spotting enemies, keeping custody of ideas, maintaining power bases, questioning the figures and the ongoing internal 'sales pitch'.

The study has also linked this process of network-building to the search for an enterprising identity and systems of organizational control. As the consultants came to see themselves as 'defenders', 'protectors' and 'promoters' of 'their business', novel forms of self-surveillance and self-discipline were created (Knights \& Willmott, 1989). This in turn generated an anxiety regarding the legitimacy of their identity as their 'value' was rationalised along market principles in the management accounting regime. This was exacerbated by the worries that value created might not be appropriated by themselves (Mueller and Dyerson, 1999). These findings suggest that actor-network studies could benefit from a more sophisticated understanding of the subjectivity of so-called 'networkbuilders'. For example, as Mulholland (1998) argues, mechanisms such as financial controls can offer a 'mythical' sense of autonomy whilst in fact facilitating a greater degree of control over employees. Indeed, what is significant about the FlexiTeam case is the anxiety and insecurity created by frequent corporate restructuring and 'cost centre' systems of management accounting, which resonates with the findings of other studies including Grey (1994), Deetz (1998) and Kosmala and Herrbach (2006: 1399-1400). This mixture of fear, loyalty and passion is similar to the 'anxiety-driven enthusiastic play acting' observed by Deetz (1998). However, our study also goes further by revealing the range of locally improvised tactics used by the consultants to position themselves as 'enterprising' employees. For example, the consultants contested, challenged and worked-around an accounting system that threatened their preferred identity as a 'valuable' and 'value-adding' business unit. They also sought to defend and protect their 'turf' from rival business units and create tactical alliances and connections - such as encouraging account managers to pass on 'leads' to them rather than rival departments. To conclude, our study has sought to question the common-sense notion that certain ideas 
gather momentum because they are more 'entrepreneurial' or 'innovative' than others. Ideas, we suggest, do not start life as 'enterprising' but rather must be made as such through the construction of a robust network.

\section{Acknowledgements}

The authors would like to thank the Economic and Social Research Council for supporting the research upon which this article is based; grant numbers 00429934467 and 026270239.

\section{Notes}

1. All names are pseudonyms.

2. For a collection of ANT studies in organization studies see Czarniawska and Hernes, 2005. For a critique see Whittle and Spicer, 2008.

3. Source: TeleCo website (address withheld for reasons of confidentiality).

4. The request for observing the performance review of one employee was refused for reasons that the review was "particularly sensitive".

5. Semi-structured interviews were conducted with all but one of the ten consultants involved in the study. One respondent was asked several times for an interview and replied that he was "too busy". The researcher did not pursue the interview after three requests for fear of being seen as too 'pushy' and damaging the research relationship.

6. Due to the quantity of tape-recorded audio-conference data the tapes were not transcribed in full (funds were not available at the time for a transcription service). The researcher made notes of the key themes of the conversations along with markers of the location on the tape to enable full transcription to be made if necessary.

\section{References}

Barley, S. R. (1996) 'Technicians in the workplace: Ethnographic evidence for bringing work into organization studies’, Administrative Science Quarterly 41(3): 404-441.

Berglund, J. and Werr, A. (2000) 'The Invincible Character of Management Consultant Rhetoric: How one Blends Incommensurates while Keeping them Apart', Organization 7(4): 633-655. 
Bryman, A. (1988) Quantity and Quality in Social Research. London: Routledge.

Buchanan, D. and Badham, R. (1999) 'Politics and Organizational Change: The Lived Experience', Human Relations 52(5): 609-629.

Callon, M. (1986) 'Some elements in a sociology of translation', in Law, J. (Ed) Power, Action and Belief, pp.196-233. London: Routledge and Kegan Paul.

Casey, C. (1995) Work, Self and Society. London: Routledge.

Clark, T. (1995) Managing Consultants. Buckingham: Open University Press.

Clark, T. and Fincham, R. (Eds) (2002) Critical Consulting: New Perspectives on the Management Advice Industry. Oxford: Blackwell.

Clarke, J. and Newman, J. (1997) The Managerial State. London: Sage.

Collinson, D. 2003. Identities and Insecurities: Selves at Work, Organization 10(3): 527547.

Czarniawska, B. and Hernes, T. (2005) (Eds) Actor-Network Theory and Organizing. Copenhagen: Liber.

Czarniawska, B. and Joerges, B. (1996) 'Travels of Ideas', in B. Czarniawska and G. Sevón (eds) Translating Organisational Change, pp.13-48. Berlin: de Gruyter.

Czarniawska, B. and Sevón, G. (2005) (Eds) Global Ideas. Brussels: Liber \& Copenhagen Business School Press.

Deetz, S. (1998) 'Discursive Formations, Strategized Subordination and Selfsurveillance' in B. McKinlay and K. Starkey (eds) Foucault, Management and Organization Theory, pp. 151-172. London: SAGE.

du Gay, P. (1996) Consumption and Identity at Work. London: Sage.

Faraj, S., Kwon, D and Watts, S. (2004) 'Sensemaking, actor networks and the shaping of the Web browser', Information, Technology and People 17(2): 186-209.

Fincham, R. (1999) 'The Consultant-Client Relationship: Critical Perspectives on the Management of Organizational Change’, Journal of Management Studies 36(3): 335351.

Fosstenløkken, S., Løwendahl, B. \& Revang, O. (2003) 'Knowledge Development through Client Interaction: A Comparative Study’, Organization Studies 24(6): 859879.

Gherardi, S. and Nicolini, D. (2005) 'Actor-Networks: Ecology and Entrepreneurs', in B. Czarniawska and T. Hernes (eds) Actor-Network Theory and Organizing, pp. 285306. Copenhagen: Liber.

Giddens, A. (2006) Modernity and Self-Identity: Self and Society in the Late Modern Age. Cambridge: Polity Press (Reprint of 1991 edition).

Grey, C. (1994) 'Career as a Project of the Self and Labour Process Discipline', Sociology 28(2): 479-497. 
Helgesson, C. and Kjellberg, H. (2005) 'Macro-actors and the sounds of the silenced', in B. Czarniawska and T. Hernes (eds) Actor-Network Theory and Organizing, pp. 145164. Copenhagen: Liber.

Kanter, R.M. (1985) The change masters: Corporate entrepreneurs at work. London: Unwin Paperbacks.

Kanter, R.M. (2000) 'When a Thousand Flowers Bloom: Structural, Collective, and Social Conditions for Innovation in Organization', in Swedberg, R. (ed.) (2000) Entrepreneurship: The Social Science View, pp. 167-210. Oxford: Oxford University Press.

Knights, D. and Willmott, H. (1989) 'Power and subjectivity at work: from degradation to subjugation in social relations', Sociology, 23(4): 535-558.

Kosmala, K and Herrbach, O. (2006) 'The ambivalence of professional identity: On cynicism and jouissance in audit firms', Human Relations 59(10): 1393-1428.

Latour, B. (2005) Reassembling the Social: An Introduction to Actor-Network Theory. Oxford: Oxford University Press.

Latour, B (1991) 'Technology is society made durable', in Law, J. (Ed) A Sociology of Monsters: Essays on Power, Technology and Domination, pp. 103-131. London: Routledge.

Latour, B. (1987) Science in Action. Cambridge, Mass.: Harvard University Press.

Law J, 1986, "On the methods of long distance control: vessels, navigation and the Portuguese route to India", in J.Law (ed.) Power, Action and Belief, pp $234-263$. London: Routledge and Kegan Paul

McGrath, K. (2002) 'The golden circle: A way of arguing and acting about technology at London Ambulance Service', European Journal of Information Systems 11: 251-266

Morris, T. and Lancaster, Z. (2006) 'Translating Management Ideas', Organization Studies 27(2): 207-233.

Mueller, F. and Dyerson, R. (1999) 'Expert Humans or Expert Organisations?', Organization Studies 20(2): 225-256.

Mulholland, K. (1998) 'Survivors' versus 'Movers and Shakers': The Reconstitution of management and Careers in the Privatised Utilities', in Thompson, P and Warhurst, C (eds) Workplaces of the Future, pp 184-203. Basingstoke: MacMillan Press.

Munro, R. (1999) 'Power and discretion: Membership work in the time of technology', Organization 6(3): 429-450.

Orlikowski, W.J. (1996) 'Improvising Organizational Transformation Over Time: A Situated Change Perspective’, Information Systems Research 7: 63-92.

Peters, T. (1992) Liberation Management. Basingstoke: Macmillan.

Rose, N. (1999) Governing the Soul. $2^{\text {nd }}$ edition, London: Free Association Books.

Sandberg, R. and Werr, A. (2003) 'The Three Challenges of Corporate Consulting', Sloan Management Review 44(3): 59-66. 
Star, S.L. (1991) "Power, technologies and the phenomenology of conventions: on being allergic to onions", in Law, J. (Eds),A Sociology of Monsters? Essays on Power, Technology and Domination, Sociological Review Monograph, No. 38, pp.26-56. London: Routledge.

Sturdy, A. (1997) 'The consultancy process - an insecure business?', Journal of Management Studies 34(3): 389-413.

Sturdy, A. (2004) 'The Adoption of Management Ideas and Practices: Theoretical Perspectives and Possibilities’, Management Learning 35(2): 153-177.

Svenningsson, S. and Alvesson, M. (2003) 'Managing managerial identities: Organizational fragmentation, discourse and identity struggle', Human Relations 56(10): 1163-1193.

Thomas, P. (2003) 'The Recontextualization of Management: A Discourse-based Approach to Analysing the Development of Management Thinking', Journal of Management Studies 40(4): 775-801.

Whittle, A. and Spicer, A. (2008) 'Is Actor Network Theory Critique?', Organization Studies 29(1).

Zilber, T.B. (2006) 'The Work of the Symbolic in Institutional Processes: Translations of Rational Myths in Israeli Hi-Tech’, Academy of Management Journal 49(2): 279-301. 


\section{Appendix}

Table of fieldwork observations and interviews.

\begin{tabular}{|l|l|l|l|l|}
\hline Fieldwork Event & Number & $\begin{array}{l}\text { Approx length } \\
\text { per event } \\
\text { (hours) }\end{array}$ & $\begin{array}{l}\text { Approx total } \\
\text { hours }\end{array}$ & $\begin{array}{l}\text { Method of data } \\
\text { recording }\end{array}$ \\
\hline $\begin{array}{l}\text { Meetings to } \\
\text { negotiate access }\end{array}$ & 5 & 2 & 10 & Field-notes \\
\hline $\begin{array}{l}\text { Team meetings } \\
\text { (monthly) }\end{array}$ & 5 & 7 & 35 & $\begin{array}{l}\text { Field-notes and } \\
\text { tape-recordings }\end{array}$ \\
\hline Client visits & 2 & 3 & 6 & Field-notes \\
\hline $\begin{array}{l}\text { Consultancy } \\
\text { Workshops }\end{array}$ & 1 & 6 & 6 & Field-notes \\
\hline $\begin{array}{l}\text { Performance } \\
\text { reviews }\end{array}$ & 4 & 1 & 4 & Field-notes \\
\hline $\begin{array}{l}\text { Social events } \\
\text { (lunches, drinks } \\
\text { after work etc) }\end{array}$ & Various & Various & Various & Field-notes \\
\hline $\begin{array}{l}\text { Work } \\
\text { shadowing/internal } \\
\text { meetings }\end{array}$ & 3 & 4 & 12 & Field-notes \\
\hline Home visits & 1 & 5 & 5 & Field-notes \\
\hline Interviews & 9 & 2 & 32 & $\begin{array}{l}\text { Tape- } \\
\text { recordings }\end{array}$ \\
\hline $\begin{array}{l}\text { Audio-conferences } \\
\text { (weekly) }\end{array}$ & 16 & 2 & N/A & Email text \\
\hline Emails & $>100$ & N/A & & \\
\hline
\end{tabular}

